\title{
Physical activity as an important element in organizing and managing the lifestyle of populations in urban and rural environments
}

\author{
Katarzyna Maria Sygit ${ }^{1, A, C-D \oplus}$, Marian Sygit ${ }^{2, A-B, F}$, Paulina Wojtyła-Buciora ${ }^{3, D-F}$, Oleg Lubiniec ${ }^{4, A-B}$, \\ Włodzimierz Stelmach ${ }^{5, D, F}$, Jan Krakowiak ${ }^{5, E-F}$ \\ ${ }^{1}$ University Faculty of Physical Culture and Health Promotion, Health Promotion Department, Szczecin, Poland \\ ${ }^{2}$ University Faculty of Physical Culture and Health Promotion, Physical Education Department, Szczecin, Poland \\ ${ }^{3}$ Department of Physiology, University of Medical Sciences, Poznań, Poland. State University of Applied Sciences, Kalisz, \\ Poland \\ ${ }^{4}$ Danylo Halytsky National Medical University, Lviv, Ukraine \\ ${ }^{5}$ Department of Social and Preventive Medicine, Medical University, Łódź, Poland \\ A - Research concept and design, B - Collection and/or assembly of data, C - Data analysis and interpretation, \\ $D$ - Writing the article, E-Critical revision of the article, F- Final approval of article
}

Sygit KM, Sygit M, Wojtyła-Buciora P, Lubiniec O, Stelmach W, Krakowiak J. Physical activity as an important element in organizing and managing the lifestyle of populations in urban and rural environments. Ann Agric Environ Med. 2019; 26(1): 8-12. doi: 10.26444/aaem/99177

\begin{abstract}
Introduction. Physical activity is one of the basic needs of people throughout their lives. Physical activity prevents many diseases, including cardiovascular diseases, which have the highest mortality rate, both among urban and rural populations in Poland. The average life expectancy in Poland and the European Union is increasing. The proportion of children and adolescents under the age of 20 is decreasing slowly but steadily, while the proportion of older people (aged 65+) in the total population is gradually increasing. According to the forecast of the Central Statistical Office, the percentage of older people increased rapidly after 2010, and will reach $22.3 \%$ in 2030 . The number of the elderly will increase from 5,134,000 in 2007 to 8,195,000 in 2030. The health situation of Poles is less favourable compared to other European Union states. The most common health risks are: nicotine, drug addiction, alcoholism and obesity. One of the causes of obesity is an unhealthy lifestyle. Lifestyle is a basic determinant of human health.

Objective. The aim of this study is to present research results based on a literature review on the importance of physical activity for human health as an element of organizing and managing the lifestyle of urban and rural populations.

Conclusions. Comprehensive measures should be taken to increase public health awareness and promote health education, especially among school-age children and youths, and to provide appropriate sports infrastructure in particularly neglected rural areas.
\end{abstract}

Key words

health, prevention, physical activity, health promotion

\section{INTRODUCTION}

Physical activity is one of the basic needs of people throughout their lives. The essence of physical activity is the physical effort associated with the work of skeletal muscles and the accompanying functional changes in the body, and energy expenditure. Physical activity inherently accompanies e.g. daily life activities, work, learning, recreation, locomotion, etc. $[1,2,3,4,5]$.

For children and youths, physical activity is like oxygen they cannot live without it. It has various functions: adaptive, compensating, stimulating and supporting development, as well as preventing development and promoting health disorders. In adulthood and old age the importance of physical activity should not be ignored. During these stages of life, physical activity prevents many diseases, premature motor involution, delays the aging process and prevents physical infirmity $[6,7,8]$.

Address for correspondence: Katarzyna Maria Sygit, University of Szczecin, Faculty of Physical Culture and Health Promotion, Health Promotion Department, Szczecin, Poland, al. Piastów 40 b, bl.6, 71-065 Szczecin, Poland

e-mail: ksygit@poczta.onet.pl

Received: 07.09.2018; accepted: 24.10.2018; first published: 26.11.2018
It is important to undertake systematic physical activity. Its proper level gives a chance for life-long physical activity. Experts on physical activity in many countries have developed recommendations and a new approach is to encourage people to increase physical effort in their daily lives. According to experts from England, Canada and the USA, the recommended level of physical activity is a minimum of 60 minutes a day at moderate intensity $[9,10,11]$.

A serious problem in all developed countries is the reduction of physical activity in both school-age children and adolescents, as well as in adults. This problem is usually observed in rural environments rather than in urban ones, which may be attributed to the lack of a proper sports infrastructure. Preference is often given to sedentary behaviours which are characterized by immobility, which include reading, watching TV or working at a computer [12, 13]. Therefore, increased efforts should be made to increase public awareness of the importance of physical activity for human health. This is the responsibility not only of doctors, but also teachers, educators, parents and health promoters. 


\section{OBJECTIVE}

The aim of this study is to present research results based on a literature review on the importance of physical activity for human health as an element of organizing and managing the lifestyle of urban and rural populations.

Physical activity in health promotion. Health promotion is a process which enables people to increase control over their own health, maintain its good level or improve it. Health is not an end in itself, but is treated as a way to achieve aspirations, meet one's needs, and transform and control the environment. Health promotion does not focus on population groups at risk of specific diseases; it rather mobilizes the whole of society to actively participate in health-related activities. These activities are aimed at influencing determinants of health $[14,15]$.

In health promotion, the concept of 'health' is understood as the human ability (which is subject to change) to achieve full physical, psychological and social capabilities, as well as responding to environmental challenges. Therefore, health is not only the lack of disease, but also the specific values of indicators which affect one's health condition. Some authors use the term 'positive health' in health promotion $[5,16]$.

All of the above-mentioned indicators of positive health are directly and indirectly affected by systematic physical training called 'health training'. Health training is a deliberately directed process, which intentionally uses strictly defined physical exercises to obtain mental and physical effects to counteract the decline in physical ability; it may also play an important role in preventing the development rate of various diseases. Therefore, health training occupies one of the most important places in the health promotion process [17].

According to the provisions of the Ottawa Charter, health promotion distinguishes five interrelated areas: building pro-health policy, creating pro-health environments, strengthening public pro-health activities, developing individual pro-health skills, and reorienting health care [12]. Each of these areas devotes a lot of space to health training, its promotion and implementation, and beneficially influences positive health indicators. Detailed recommendations on the dosage, form and intensity of the physical effort recommended in health promotion coincide with those proposed in the primary prevention of ischemic heart disease [18].

Average life expectancy in Poland and the European Union. The Polish population decreased after 1996 and at the end of 2007 it amounted to 38,115,600. According to the latest forecast of the Central Statistical Office (GUS), the Polish population will systematically decrease until 2035 and the forecast decline in this period may amount to approx. $2,120,000$ people. Primarily, the number of city dwellers will decrease.

The proportion of children and youths under the age of 20 is decreasing slowly but steadily, while the proportion of older people (aged 65+) in the total population is gradually increasing. According to the Central Statistical Office, the percentage of older people increased quickly after 2010, and according to the prognosis it will reach $22.3 \%$ in 2030 . The number of the elderly will increase from 5,134,000 in 2007 to $8,195,000$ in 2030, an increase of 3 million.

Analysis of the mortality data of Poles indicates that the health condition of the population since 1991 has gradually improved, but the situation is still unsatisfactory compared to other EU countries; additionally, in 2000, the improvement slowed down, especially among men.

The average life expectancy in Poland has also been increasing since 1991, but after 2002, the growth slowed down. In 2007, the lifespan of men was 71.0 years, while for women it was almost 9 years longer (79.7 years). After 2001, the unfavourable differences between the life expectancy of men and women started to deepen. In 2016, women's life expectancy was 81.5 and men's - 73.5 years. According to Eurostat estimates, men in Poland maintain good health (without limited efficiency) for $86 \%$ of life expectancy, while women for $84 \%$. People aged 65 can expect to live in health for more than a half of their remaining lives - women for almost 2 years longer than men.

The life expectancy of Poles is clearly shorter than the average in the European Union - men live shorter by 4.6 years and women by 2 years. Unless more intense actions are taken to improve the health of Polish society, achieving the current EU average life expectancy in Poland may take several dozen years for men (Fig. 1). Life expectancy is strongly differentiated by social factors: people aged 25 with higher education may expect to live longer than people with primary education by about 13 years (men) and 9 years (women) [19].

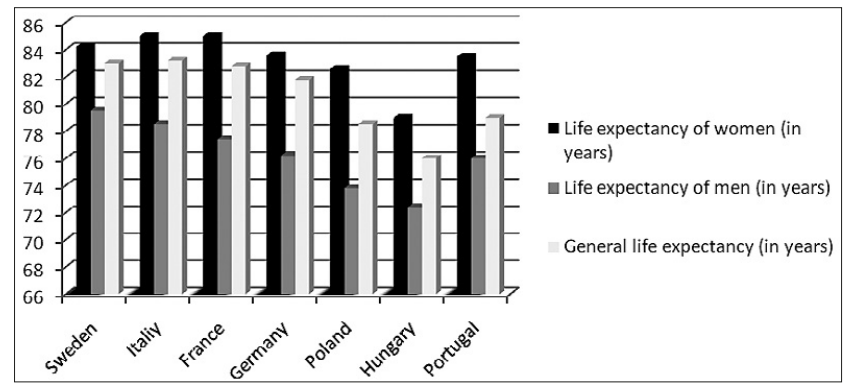

Figure 1. Average life expectancy in Poland and in selected European countries. Source: Central Statistical Office (2016), http://www.stat.gov.pl [19]

Poland clearly suffers from the unfavourable phenomenon of inordinate mortality of men in relation to women, and consequently, the much shorter remaining lifespan of men, regardless of their age. Worryingly, there is no improvement in this regard, and after 2001, the unfavourable differences between the life expectancy of men and women started to deepen. It is estimated that two-thirds of this difference is due to higher premature (before the age of 65) mortality among men than women, and one-third is related to higher mortality in the population aged over 65 . The problem of the significantly shorter life expectancy of men seems to be ignored by health policy programs $[19,20,21,22]$.

Lifestyle is the basic determinant of human health. The health of the individual and the community in all cultures depends on many different factors. The role and hierarchy of the importance of individual factors may vary and change with the modifications in the health model. The groundbreaking moment in perceiving the significance of individual factors was the report of the Minister of Health of Canada, M. Lalonde (1974), which formed the basis of the State's health policy (Fig. 2) [23, 24].

The concept of 'health fields' had an impact on the development of the socio-ecological health model and change 


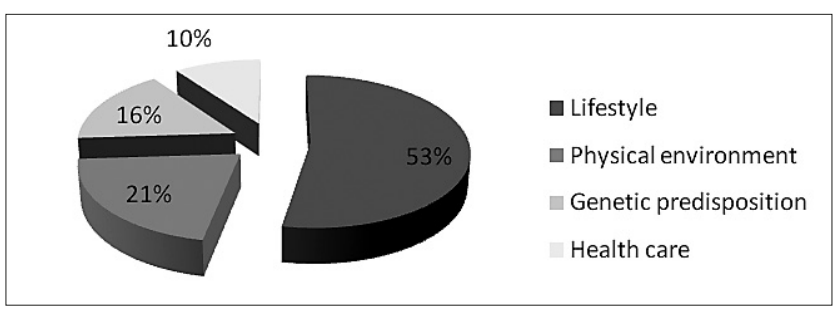

Figure 2. Factors determining the health of an individual according to the concept of 'health fields' (own work based on Lalonde, 1974).

Source: B. Woynarowska, Edukacja zdrowotna, PWN, Warsaw 2017, p. 45 [24]

in health policy worldwide. It made people aware that their lifestyle greatly influences their health; and by implementing beneficial changes, one's health may be improved $[24,25]$.

'Lifestyle' should be understood as 'a way of life'. The concept was introduced to psychology by Alfred Adler. It concerns an individual way of being, specific for a given person, including their characteristics, interests, values, etc. Lifestyle depends on the environment the person identifies with, social norms, personal beliefs and values, and the general economic and political structure of the society. Therefore, lifestyle consists of proper nutrition, maintaining comprehensive physical activity, developing the ability to fight stress, maintaining the body's defences in constant readiness, boosting the immune system, avoiding drug abuse, elimination of addictions, friendliness towards others, and maintaining a coping attitude $[23,26]$.

When considering the relationship between lifestyle and health, different terms are used: healthy lifestyle, healthfriendly lifestyle, health-oriented lifestyle, pro-health lifestyle, etc. Pro-health lifestyle means that people consciously undertake activities aimed at increasing the potential of their health and eliminate behaviours that threaten health. In the opinion of A. Ostrowska in a study on health-promoting lifestyle, the concept of 'lifestyle' should be considered only in terms of various health-related behaviours. Among these behaviours, physical activity deserves special attention [27].

There are numerous benefits of an active lifestyle and include, among others:

a. Reducing the risk of obesity - increasing data indicate that the reduction in physical activity is the main factor responsible for increasing the incidence of obesity. Many studies have shown the beneficial effect of physical activity and pro-health lifestyle on the prevention of obesity. It seems that physical activity particularly protects against the increase of body mass, which is typical of middle age.

b. Reducing the risk of heart disease - people who lead an active lifestyle (which includes moderate physical activity) have a $50 \%$ lower risk of heart disease than those with a sedentary lifestyle. Even obese people who are active have a lower risk of heart disease and diabetes than those who do not exercise.

c. Reducing the risk of diabetes - lack of physical activity is a risk factor for type 2 diabetes. People with high physical activity have a reduced risk of developing diabetes by 33 $50 \%$. Interestingly, in people with diabetes, physical activity facilitates achieving a good control of concentration of sugar in blood.

d. Reducing the risk of cancer - moderate and high physical activity reduces the risk of developing cancer of the large intestine, lungs and breasts. e. Healthy muscles and bones - regular physical activity strengthens muscles, tendons and ligaments, and promotes greater bone density. Some forms of activity, such as running, roller-skating and dancing, increase bone density in teenagers, maintain high bone density in adults and slow the loss of bone density in older people (which would lead to osteoporosis).

f. Impact on mental health - several studies have shown that physical activity improves mental well-being, facilitates coping with stress and improves some mental skills (such as speed of decision making, planning and short-term memory), reduces anxiety and improves sleep quality. Data from clinical trials show that physical activity may be used to treat depression. In the elderly, physical activity may reduce the risk of dementia and Alzheimer's disease $[11,28,29,30,31,32]$.

Physical activity of adolescents. HBSC 2016 (Health Behavior In School-aged Children) research on health behaviours of adolescents from 39 European countries, as well as Israel, Canada, the USA, conducted in Poland by the Mother and Child Institute, indicated that in the 2014 - 2015 school year, only $18 \%$ of young people aged $11-18$ undertook moderate physical activity in the recommended daily dose. These results refer to the total time spent on physical activity, both in physical education classes, as well as in various additional activities and leisure. The research shows that the physical activity of adolescents significantly decreases at school age. As many as $24.4 \%$ of students do not participate in PE classes.

According to the Ministry of Sport and Tourism, none of the educational levels displays a satisfactory percentage of physically active students. However, a drastic decline in physical activity in adolescents who enter subsequent stages of education, should be more worrying. The downward trend of physical activity among girls is particularly strong [33].

Risks to human health resulting from low physical activity. The health situation of Poles is less favourable compared to other European Union states. Important health risks include nicotinism, drug addiction, alcoholism, obesity, (currently, there are a billion overweight adults and over 300 million obese worldwide, and the problem of excessive fat tissue also affects more and more people in Poland), chronic diseases, disorders of the motor system, and risky sexual behaviours $[29,34,35]$. Additionally, there are biological risks (epidemics caused by microorganisms or parasites); chemical (pollution of air, water, food); physical (vibrations, noise); geological (e.g. soil degradation) [34]. However, the biggest risks are overweight and obesity, which have enormous health consequences.

The incidence of overweight and obesity in developed countries (including Poland) is constantly growing, and currently it is one of the most common health-related problems associated with lifestyle. The problem of excessive body mass in Poland is experienced by men more often (44\% overweight and $18.1 \%$ obese) than women $(30.1 \%$ and $15.6 \%$, respectively) (Tab. 1). The situation was similar in the $28 \mathrm{EU}$ countries. The percentage of overweight men in the EU totalled an average of $41.7 \%$ and ranged from $36.7 \%$ in Estonia to $52.2 \%$ in Romania. The percentage of obese men (15.6\% on average) ranged from $8.7 \%$ in Romania to $27.2 \%$ in Malta. The percentage of overweight women, 
on average, was $28.3 \%$ in the EU and was the lowest in Denmark (24.3\%), while the highest in Romania (38.0\%). The percentage of obese women (on average 15.3\%) ranged from $9.4 \%$ in Romania to $23.3 \%$ in Malta. The percentage of overweight and obese people is growing steadily. In Poland in 1996 , this amounted to $27.7 \%$, in 2004 it rose to $29.6 \%$, while in 2009 it reached 53\%. The increase was also witnessed in other EU countries. Between 2008 - 2014, the share of obese people increased by 1.5 percentage point among the $24 \mathrm{EU}$ countries $[2,36]$.

Table 1. Body weight of adult Poles (in \%).

\begin{tabular}{ccccccccc}
\hline & \multicolumn{2}{c}{ Underweight } & \multicolumn{2}{c}{ Normal weight } & \multicolumn{2}{c}{ Overweight } & \multicolumn{2}{c}{ Obesity } \\
\cline { 2 - 9 } & W & M & W & M & W & M & W & M \\
\hline 1996 & 15,9 & 5,9 & 57,5 & 65,1 & 14,2 & 18,7 & 12,4 & 10,3 \\
\hline 2004 & 16,5 & 5,6 & 56,7 & 61,7 & 14,2 & 19,8 & 12,5 & 12,6 \\
\hline 2009 & 4,3 & 1,3 & 51,0 & 37,4 & 29,4 & 44,8 & 15,2 & 16,6 \\
\hline 2014 & 4,2 & 1,2 & 50,1 & 36,6 & 30,1 & 44,1 & 15,6 & 18,1
\end{tabular}

Source: authors' own work based on: Woynarowska B. (editors) Edukacja zdrowotna, PWN, Warsaw 2017 (in Polish) [24]

Obesity is treated as a separate disease. It is the third risk factor for other diseases, after arterial hypertension and smoking. It is estimated that obesity may account for $5 \%$ to over $20 \%$ of deaths per year in the USA and $10 \%-13 \%$ in Europe. Research indicates that the obesity epidemic may soon lead to a decrease in the average life expectancy. Among health consequences of overweight and obesity, one may list: cardiovascular complications (including hypertension, ischemic heart disease, lipid disorders), respiratory complications (including sleep apnoea and asthma), neurological complications (including stroke and dementia), gastrointestinal and hepatic complications (including type 2 diabetes and pre-diabetes), endocrine complications (including impaired fertility and premature puberty), osteochondral complications (including degenerative joint diseases, backache), renal complications, and psychosocial consequences (among others: low self-esteem, anxiety, depression, eating disorders, reduced learning skills), and numerous cancers. Potentially negative health consequences may also be caused by attempts to reduce body mass by improper slimming measures and radical starvation [37, $38,39,40,41]$.

In many epidemiological studies the effect of reduced physical activity on the development of obesity worldwide has been confirmed. Physical activity is one of basic elements of comprehensive obesity treatment. Systematic exercise, which increases energy expenditure, not only promotes weight loss, but also causes many other beneficial changes in the human body, such as increased muscle and bone mass, improved glucose tolerance and lipid profile, reduced heart rate and blood pressure during physical activity and resting, improvement in general well-being and mental health. The recommendation of physical activity should include both increased daily basic physical activity and planned physical exercises of medium intensity for at least 30 minutes a day during leisure - every day, if possible. Such exercises should be tailored to the individual possibilities and preferences of the patient, and enable the loss of approximately $300 \mathrm{kcal}$ during one exercise session. Due to the co-existing degenerative changes of the motor system, the recommended form of exercise for the obese are 'relief exercises' (i.e. exercises in water, riding a bicycle), which do not place direct pressure on the joints of the lower limbs [42, 43, 44, 45, 46, 47].

The health situation of Poles. Cancer was the leading cause of death and in 2012 in the EU the mortality rate amounted to 166.9 deaths per 100,000 inhabitants. However, cardiovascular diseases have invariably been the most common cause of mortality in Poland for over 50 years [18]. In 2015, approx. $45 \%$ of deaths were caused by cardiovascular diseases, which resulted in almost 178,000 deaths of Poles 83,613 men and 94,352 women. The most frequent cause of mortality among cardiovascular diseases in Poland is still ischemic heart disease and cerebrovascular disease. Deaths due to these two groups of diseases account for almost 50\% of deaths from cardiovascular diseases among men and $44 \%$ among women. The current health situation results from the dominance of the anti-health lifestyle of Poles from the urban and rural environments [16].

\section{CONCLUSIONS}

1. The basic factor of human health is a pro-health lifestyle, in which physical activity plays a vital role.

2. In Poland, sedentary behaviours prevail, both in the urban and rural population, which is similar to other European Union countries.

3. Due to an unhealthy lifestyle, the population worldwide is at the risk of obesity, cardiovascular disease, and cancer.

4. Effective health education which promotes a healthy lifestyle is indispensable; it should include increased physical activity of the population and the development of appropriate sports infrastructure, both in the urban and rural environments.

\section{REFERENCES}

1. Wojtyła-Buciora P, Bołdowski T, Żukiewicz-Sobczak W, Wojtyła C, Wojciechowska M, Wojtyła A, Pawłowska A, Krauss H. The impact of the "Keep Fit" national programme in Poland on diet, physical activity and health during 2006-2011 in children and adolescents. J Health Inequal. 2016; 2(1): 67-76.

2. Bergier J. Studies and measurements of physical activity of the society. Ann Agric Environ Med. 2012; 19(3): 329-331.

3. Wojtyła-Buciora P, Bołdowski T, Wojtyła C, Żukiewicz-Sobczak W, Wojtyła K, Chęcińska-Maciejewska Z, Wojtyła A, Krauss H. The "Keep Fit!” programme for building health-competence in children and adolescents in Poland regarding their diet and physical activity-study design. J Health Inequal. 2016; 2(2): 172-177.

4. Hamer M, Stamatakis E, Steptoe A. Dose-response relationship between physical activity and mental health: the Scottish Health Survey. Br J Sports Med. 2009; 43(14): 1111-1114. doi: 10.1136/bjsm.2008.046243.

5. Kruk J. Physical activity and health. Asian Pacific J Cancer Prev. 2009; 10(4): 721-728.

6. Lee I, Skerritt P. Physical activity and all-cause mortality: what is the dose-response relation? Medicine and Science In Sports and Exercise. 2001; 33(6): 459-471.

7. Lund Nilsen T, Vatten L. Prospective study of coclorectal cancer risk and physical activity. Brit J Cancer. 2001; 84(4): 417-422.doi:10.1054/ bjoc. 2000.1582 .

8. Prochaska J, Sallis J, Long B. A physical activity screening measure for use with adolescents in primary care. Arch Pediatr Adolesc Med. 2001; 155(9): 554-9. PMID:11343497.

9. Strong W, Malina R, Blimkie C, Daniels S, Dishman R, Gutin B. Evidence based physical activity for school-age youth. J Pediatr. 2005; 146(6): 732-737. doi: 10.1016/j.jpeds.2005.01.055. 
10. Craig C, Marshall A, Sjostrom M, Bauman A, Booth M, Ainsworth B. International physical activity questionnaire: 12 -country reliability and validity. Med Sci Sports Exerc. 2003; 35(8): 1381-1395. doi:10.1249/01. MSS.0000078924.61453.FB.

11. Delisle T, Werch C, Wong A. Relationship Between Frequency and Intensity of Physical Activity and Health Behaviours of Adolescents. J Sch Health. 2010; 80 (3): 134-140. doi:10.1111/j.1746-1561.2009.00477.x.

12. Bergier J, Kapka-Skrzypczak L, Biliński P, Paprzycki P, Wojtyła A. Physical activity of Polish adolescents and young adults according to IPAQ: a population based study. Ann Agric Environ Med. 2012; 19(1): 109-115. PMID:22462455.

13. Łobaszewski J, Przewoźniak K, Zatońska K, Wojtyła A, Bylina J, Mańczuk M. Patterns of leisure time physical activity and its determinants among a sample of adults from Kielce region, Poland - the 'PONS' study. Ann Agric Environ Med. 2011; 18(2): 241-245. PMID:22216789.

14. Sygit K, Nasiłowska-Barud A, Karwat ID, Gorczyca R, Jędrych M, Kołłątaj W. Selected social and health problems in functioning of disabled rural and urban inhabitants in the Lublin Region - similarities and differences. Ann Agric Environ Med. 2010; 17(2): 287-299. PMID:21186772.

15. Ziglio E, Hagard S, Griffiths J. Health promotion development In Europe: achievements ans challenges. Health Promotion International 2000; 15(3): 143-154. https://doi.org/10.1093/heapro/15.2.143.

16. Mazur J. Zdrowie i zachowania zdrowotne młodzieży szkolnej w Polsce na tle wybranych uwarunkowań socjodemograficznych, wyniki badania HBSC, HBSC [Health and health behaviors of school-aged adolescents in Poland against the backdrop od socio-demographic conditions, the HBSC research results, HBSC] Warszawa, 2015. (in Polish).

17. Erickson K, Michelle W, Voss M. Exercise training increases size of hippocampus and improves memor. PNAS. 2011; 108(7): 3017-3022. doi: 10.1073/pnas.1015950108.

18. Makowiec-Dąbrowska T. Wpływ aktywności fizycznej w pracy i życiu codziennym na układ krążenia [The effects of physical activity at work and everyday life on the cardiovascular system] Forum Med Rodz. 2012; 6(3): 130-138. (in Polish)

19. Główny Urząd Statystyczny [Main Statistical Office] (2016), http:// www.stat.gov.pl (access: 2018.07.02). (in Polish)

20. Wojtyła A, Kapka-Skrzypczak L, Biliński P, Paprzycki P. Physical activity among women at reproductive age and during pregnancy (Youth Behavioural Polish Survey - YBPS and Pregnancy-related Assessment Monitoring Survay - PrAMS) - epidemiological population studies in Poland during the period 2010-2011. Ann Agric Environ Med. 2011; 18(20): 365-374. PMID:22216814.

21. Wojtyniak B., Goryński P. Sytuacja zdrowotna ludności Polski [Health situation of the Polish population] Narodowy Instytut Zdrowia Publicznego - Państwowy Zakład Higieny, Warszawa, 2008. (in Polish)

22. Pięta B, Chmaj-Wierzchowska K, Opala T. Life style and risk of development of breast and ovaria cancer. Ann Agric Environ Med. 2012; 19(3): 379-384.PMID:23020026.

23. Sygit K, Kołłątaj W, Wojtyła A, Sygit M, Bojar I, Owoc A. Engagement in risky behaviours by 15-19-year-olds from Polish urban and rural areas. Ann Agric Environ Med. 2011; 18(2): 404-409. PMID:22216820.

24. Woynarowska B. (editors) Edukacja zdrowotna [Health education] PWN, Warszawa, 2017 (in Polish).

25. Woynarowska B. (editors) Aktywność fizyczna: profilaktyka w pediatrii [Physical activity: prevention in pediatrics] PZWL, Warszawa. 2008 (in Polish).

26. Litwic-Kamińska K, Izdebski P. Pojęcie i samoocena zdrowia oraz zachowania zdrowotne a poziom aktywności fizycznej w okresie wczesnej dorosłości [The concept and self-assessment of health and health behaviors versus the level of physical activity in young adulthood] Med Sport 2012; 3(4): 167-178. (in Polish)

27. Ostrowska A. Styl życia a zdrowie [Lifestyle versus health] Wyd. IFiS PAN, Warszawa, 1999 (in Polish).

28. Blair S.N, Hardman A. Special issue: Physical activity, health and wellbeing - an international scientific consensus conference. Reasearch Quarterly for Exercise and Sport. 1995; 66(4): 24-28.
29. Word Health Organization. Ottawa Charter for health promotion, Health Promotion International 1(4) III-IV, 1986.

30. Brody J, Rudel R, Michels K, Moysich K, Berbstein L, Attfield K, Gray S. Environmental pollutants, diet, physical activity, body size, and Brest cancer. Cancer 2007; 109(4): 2627-2634. DOI:10.1002/cncr.22656.

31. Garabrant D, Peters J, Mack T, Bernstein L. Job activity and colon cancer risk. Am J Epidemiol. 2014; 119(6): 1005-1014.PMID:6731427.

32. Sallis JF, Prochaska J, Taylor W. A review of correlates of physical activity of children and adolescents. Med. Sci Sport Exerc. 2000; 32(2): 963-975. PMID:10795788.

33. HBSC 2015 https://www.msit.gov.pl/pl (access: 2018.06.13).

34. Zatoński W. HEM project team. Epidemiological analysis of health situation development in Europe and its causes until 1990. Ann Agric Environ Med. 2011, 18(2): 194-202.

35. Cooper A, Sebire S, Montgomery A. Sedentary time, breaks in sedentary time and metabolic variables in people with newly diagnosed type 2 diabetes. Diabetol. 2012; 55(3): 589-599. doi: 10.1007/s00125-0112408-x.

36. Shamah Levy T, Morales Ruán C, Amaya Castellanos C. Effectiveness of a diet and physical activity promotion strategy on the prevention of obesity in Mexican school Children. BMC Public Health. 2012; 1(12): 152-155. doi: 10.1186/1471-2458-12-152.

37. Plewa M, Markiewicz M. Aktywność fizyczna w profilaktyce i leczeniu otyłości [Physical activity in prevention and treatment of obesity] Endokrynologia, Otyłość i Zaburzenia Przemiany Materii. 2006; 2(1): 30-34. (in Polish)

38. Stępniak U. Prevalence of general and abdominal obesity and overweight among adults in Poland. Results of the WOBASZ II study (2013-2014) and comparison with the WOBASZ study (2003-2005). Polskie Archiwum Medycyny Wewnętrznej. 2016; 126(9): 662-671. (in Polish)

39. Loring B, Robertson A. Otyłość i nierówności. Praktyczne aspekty przeciwdziałania nierównościom związanym z nadwagą i otyłością [Obesity and inequality. Practical aspects of counteracting inequality related to overweight and obesity] WHO, 2014. (in Polish)

40. Manson J, Skerrett P, Greenland P, Van Itallie TB. The escalating pandemics of obesity and sedentary life style. A call to action for clinicians. Arch Intern Med. 2004; 164(3): 249-58. DOI:10.1001/ archinte.164.3.249.

41. Monda K, Adair L, Zhai F, Popkin B. Longitudinal relationships between occupation and domestic physical activity patterns and body weight in China. Eur J Clin Nutr. 2008; 62(11): 1318-25. DOI:10.1038/ sj.ejen.1602849

42. Branca F, Nikogosian H, Lobstein T. The challenge of obesity In the WHO European Region and the strategies for response. World Health Organization 2007. http://www.euro.who.int/data/assets/ pdf_file/0008/98243/E89858.pdf (access:2018.07.01).

43. Masters R. The impact of obesity on US mortality levels: the importance of age and cohort factors in population estimates. Am J Public Health. 2015; 103(10): 1895-1901. doi: 10.2105/AJPH.2013.301379.

44. Woynarowska B. Aktywność fizyczna dzieci i młodzieży [Physical activity of children and adolescents] Polskie Forum Profilaktyki Chorób Układu Krążenia (PFP). 2008; 3(12): 5-15. (in Polish)

45. Global recommendations on physical activity for health. Geneva, World Health Organization, 2010. http://www.who.int/dietphysicalactivity/ factsheet_recommendations/en/index.html(acces: 2018.06.15).

46. Forouzanfar M. Global, regional, and national comparative risk assessment of 79 behavioural, environmental and occupational, and metabolic risks or clusters of risks in 188 countries, 1990-2013: a systematic analysis for the Global Burden of Disease Study 2013. Lancet. 2013; 386(1010): 2287-2323. doi: 10.1016/S0140-6736(16)31679-8.

47. Wojtyła-Buciora P, Bołdowski T, Wojtyła C, Żukiewicz-Sobczak W, Juszczak K, Łabędzka-Gardy M, Wojtyła A, Krauss H. An all-Poland survey of physical activity and sedentery life style for middle school, high school and university students. J Health Inequal 2017; 3(1): 70-77. 